\title{
Nurmipalkokasveja viljelyyn ja laidunnukseen Pohjois-Pohjanmaalle
}

\author{
Marika Laurila, Arto Huuskonen ja Sirkka Luoma \\ Maa- ja elintarviketalouden tutkimuskeskus, Kotieläintuotannon tutkimus, Tutkimusasemantie 15, \\ 92400 Ruukki,marika.laurila@mtt.fi, arto.huuskonen@mtt.fi,sirkka.luoma@mtt.fi
}

\section{Tiivistelmä}

Tutkimuksessa haluttiin selvittää, millaisilla palko- ja heinäkasvilajien yhdistelmillä voitaisiin päästä korkeisiin ja laadukkaisiin kuiva-ainesatoihin Pohjois-Suomen olosuhteissa. Koe toteutettiin satunnaistettujen lohkojen osaruutukokeena MTT Ruukin toimipisteessä vuosina 2003-2005. Pääruutuna oli heinäkasvilaji (joko timotei-nurminataseos tai timotei-ruokonataseos) ja osaruutuna palkokasvi, jota viljeltiin seoksena heinäkasvien kanssa. Kokeessa käytetty timoteilajike oli Tammisto II, nurminatalajike Kasper ja ruokonatalajike Retu. Osaruutuina olleita palkokasvivaihtoehtoja oli kaikkiaan 7 kappaletta: ei palkokasvia, valkoapila (Jögeva 4), puna-apila (Betty), alsikeapila (Frida), keltamaite (Leo), rehumailanen (Karlu) ja rehumailanen (Juurlu). Kokeessa oli neljä kerrannetta, eli ruutumäärä oli 56. Vuonna 2004 nurmet ja apilat niitettiin neljä kertaa ja keltamaite sekä rehumailaset kolme kertaa. Vuonna 2005 kaikki kasvilajit niitettiin kolme kertaa.

Heinäkasvilaji ei vaikuttanut tilastollisesti merkitsevästi kuiva-aineen kokonaissatoon $(\mathrm{kg}$ $\mathrm{ka} / \mathrm{ha}$ ), muuntokelpoisen energian satoon (GJ/ha) eikä raakavalkuaissatoon ( $\mathrm{kg} / \mathrm{ha}$ ) kumpanakaan koevuonna. Myöskään heinäkasvi×palkokasvi -yhdysvaikutus ei ollut tilastollisesti merkitsevä kumpanakaan koevuonna. Kokeen keskimääräinen kokonaiskuiva-ainesato oli $5501 \mathrm{~kg} \mathrm{ka} / \mathrm{ha}$ vuonna 2004 ja 4 $724 \mathrm{~kg} \mathrm{ka} / \mathrm{ha}$ vuonna 2005. Muuntokelpoisen energian sato oli vastaavasti keskimäärin $60,1 \mathrm{GJ} / \mathrm{ha}$ vuonna 2004 ja 51,4 GJ/ha vuonna 2005.

Palkokasvivalinta vaikutti merkitsevästi kuiva-aine-, energia- ja raakavalkuaissatoihin molempina koevuosina. Vuonna 2004 suurimmat kuiva-aine- ja energiasadot mitattiin puhtaista nurmiheinäkasvustoista (6 200-6700 kg ka/ha, 68-73 GJ/ha) sekä nurmiheinäkasvin ja valkoapilan seoskasvustoista (6 300-6 $700 \mathrm{~kg} \mathrm{ka} / \mathrm{ha}, 69-74 \mathrm{GJ} / \mathrm{ha}$ ). Myös heinäkasvin ja puna-apilan seoskasvustoilla saavutettiin tällöin yli $5600 \mathrm{~kg} \mathrm{ka} / \mathrm{ha}$ kuiva-ainesadot ja yli $60 \mathrm{GJ} / \mathrm{ha}$ energiasadot. Pienimmiksi satotasot jäivät keltamaitetta sisältäneillä seoskasvustoilla (3 900-4 $100 \mathrm{~kg} \mathrm{ka} / \mathrm{ha}, 44-46 \mathrm{GJ} / \mathrm{ha})$. Vuoden 2005 osalta satotasotulokset olivat pääosin samansuuntaiset kuin vuonna 2004, mutta satomäärät jäivät tällöin hieman vuotta 2004 alhaisemmalle tasolle. Vuonna 2005 korkeimmat kuiva-ainesadot mitattiin apilaa sisältävistä seoskasvustoista (4 650-5 $600 \mathrm{~kg} \mathrm{ka/ha)} \mathrm{sekä} \mathrm{puhtailta} \mathrm{nurmiheinäkasviruuduilta} \mathrm{(4}$ $600-5300 \mathrm{~kg} \mathrm{ka} / \mathrm{ha}$ ). Rehumailasta ja keltamaitetta sisältäneillä ruuduilla kuiva-ainesadot vaihtelivat välillä 3 700-4 $500 \mathrm{~kg} \mathrm{ka/ha,} \mathrm{mutta} \mathrm{tällöin} \mathrm{suurin} \mathrm{osa} \mathrm{sadosta} \mathrm{muodostui} \mathrm{heinäkasveista} \mathrm{sekä} \mathrm{rikoista.}$

Tulosten perusteella apilat osoittautuivat mailasia ja keltamaitetta paremmiksi ja viljelyvarmemmiksi vaihtoehdoiksi nurmiheinäkasvien ja nurmipalkokasvien seosviljelyyn Pohjois-Pohjanmaan olosuhteissa.

Asiasanat: nurmet, rehuntuotanto, nurmipalkokasvit, nurmiheinäkasvit, timotei, nurminata, ruokonata, puna-apila, valkoapila, alsikeapila, keltamaite, rehumailanen, satotaso, sulavuus, rehun laatu, valkuainen, kuitu 


\section{Johdanto}

Tutkimuksella haluttiin selvittää, millaisilla palko- ja heinäkasvilajien yhdistelmillä voitaisiin päästä korkeisiin ja laadukkaisiin kuiva-ainesatoihin Pohjois-Suomen olosuhteissa. Työ perustui MTT Ruukin toimipisteessä vuosina 2003-2005 toteutettuun ruutukokeeseen. Kokeissa olivat heinäkasveista mukana timotei-nurminataseos ja timotei-ruokonataseos, joita viljeltiin joko puhtaana kasvustona tai seoksena palkokasvien kanssa. Palkokasveista olivat mukana puna-apila, valkoapila, alsikeapila, keltamaite sekä kaksi rehumailaslajiketta (virolaiset lajikkeet Karlu ja Juurlu). Koe toteutettiin niittämällä koeruudut useita kertoja kasvukauden aikana, jotta tulokset olisivat sovellettavissa laidunnukseen.

\section{Aineisto ja menetelmät}

Koe toteutettiin satunnaistettujen lohkojen osaruutukokeena. Pääruutuna oli heinäkasvilaji (joko timotei-nurminataseos tai timotei-ruokonataseos) ja osaruutuna palkokasvi, jota viljeltiin seoksena heinäkasvien kanssa. Kokeessa käytetty timoteilajike oli Tammisto II, nurminatalajike Kasper ja ruokonatalajike Retu. Osaruutuina olleita palkokasvivaihtoehtoja oli kaikkiaan 7 kappaletta: ei palkokasvia, valkoapila (Jögeva 4), puna-apila (Betty), alsikeapila (Frida), keltamaite (Leo), rehumailanen (Karlu) ja rehumailanen (Juurlu). Kokeessa oli neljä kerrannetta, eli ruutumäärä oli 56. Taulukossa 1 on esitetty kylvömäärät ja seossuhteet. Suojaviljana ollut ohra (Arve $107 \mathrm{~kg} / \mathrm{ha}$ ) kylvettiin 2.6.2003. Kokeessa olleet nurmikasvit kylvettiin 3.6.2003. Suojavilja niitettiin pois 4.8.2003.

Taulukko 1. Koeruutujen kylvömäärät (kg/ha) keväällä 2003.

\begin{tabular}{lrrrr}
\multicolumn{5}{c}{ Kylvömäärä, kg/ha } \\
\hline seos & palkokasvi & timotei & nurminata & seoksista käytetyt lyhenteet \\
\hline timotei-nurminata & - & 10 & 15 & tn \\
valkoapila, Jögeva 4 & 3 & 5 & 7 & tn-valkoapila \\
puna-apila, Betty & 5 & 6 & 8 & tn-puna-apila \\
alsikeapila, Frida & 4 & 5 & 7 & tn-alsikeapila \\
keltamaite, Leo & 4 & 4 & 6 & tn-keltamaite \\
rehumailanen, Karlu & 7 & 5 & 7 & tn-Karlu \\
rehumailanen, Juurlu & 7 & 5 & 7 & tn-Juurlu \\
\hline seos & palkokasvi & timotei & ruokonata & seoksista käytetyt lyhenteet \\
\hline timotei-ruokonata & - & 10 & 15 & tr \\
valkoapila, Jögeva 4 & 3 & 5 & 7 & tr-valkoapila \\
puna-apila, Betty & 5 & 6 & 8 & tr-puna-apila \\
alsikeapila, Frida & 4 & 5 & 7 & tr-alsikeapila \\
keltamaite, Leo & 4 & 4 & 6 & tr-keltamaite \\
rehumailanen, Karlu & 7 & 5 & 7 & tr-Karlu \\
rehumailanen, Juurlu & 7 & 5 & 7 & tr-Juurlu \\
\hline
\end{tabular}

Viljavuustutkimus ennen kokeen perustamista antoi seuraavat perustiedot: pH 6,00, kalsium 1076 mg/l, fosfori $18 \mathrm{mg} / \mathrm{l}$, kalium $60 \mathrm{mg} / \mathrm{l}$, magnesium $128 \mathrm{mg} / \mathrm{l} \mathrm{ja} \mathrm{Ca/Mg-suhde} \mathrm{8,41.} \mathrm{Lohkon} \mathrm{maalaji} \mathrm{oli}$ karkea hieta ja multavuusluokka runsasmultainen. Ennen kylvöä (2.6.2003) koealalle levitettiin lietelantaa $21 \mathrm{tn} / \mathrm{ha}$. Lanta-analyysin mukaan lietelannassa oli ravinteita seuraavasti: liukoinen typpi 1,6 $\mathrm{kg} / \mathrm{tn}$, kokonaistyppi $2,4 \mathrm{~kg} / \mathrm{tn}$, fosfori $0,13 \mathrm{~kg} / \mathrm{tn}$ ja kalium 2,2 kg/tn. Vuonna 2004 ei tehty kevätlannoitusta, mutta ensimmäisen niiton jälkeen puhtaille heinäkasviruuduille annettiin typpilannoitus 88 $\mathrm{kg} / \mathrm{ha}$ sekä kaikille ruuduille kaliumlannoitus $60 \mathrm{~kg} / \mathrm{ha}$. Toisen niiton jälkeen puhtaille heinäkasviruuduille annettiin typpilannoitus $66 \mathrm{~kg} / \mathrm{ha}$ sekä puhtaille heinäkasviruuduille ja apilalle kaliumlannoitus $44 \mathrm{~kg} / \mathrm{ha}$. Vuonna 2005 annettiin (13.5.) puhtaille heinäkasviruuduille typpilannoitus $77 \mathrm{~kg} / \mathrm{ha}$ ja kaikille ruuduille (17.5.) fosforilannoitus $20 \mathrm{~kg} / \mathrm{ha}$.

Vuonna 2004 nurmet ja apilat niitettiin neljä kertaa ja keltamaite sekä rehumailaset kolme kertaa. Vuonna 2005 kaikki kasvilajit niitettiin kolme kertaa. Taulukossa 2 on esitetty niittojen ajankohdat molempina koevuosina. Jokaisen niiton yhteydessä kasvustosta mitattiin eri kasviryhmien osuudet tuorepainosta (vakioimaton osanäyte), kokonaiskuiva-ainesato, tuhka, raakavalkuainen, sulavuus ja NDF. D-arvot määritettiin käyttäen Huhtasen ym. (2006) raportoimaa orgaanisen aineen pepsiinisellulaasiliukoisuuteen pohjautuvaa yleiskaavaa. Lisäksi mitattiin kasvustojen syys- ja kevättiheydet 
talvenkestävyyden arvioimiseksi. Kokeen tulokset analysoitiin tilastollisesti käyttäen SAS 9.2:n Mixed-proseduuria. Tulokset analysoitiin erikseen vuosittain ja niitoittain mallilla, jossa kiinteinä muuttujina olivat heinäkasvilaji, palkokasvilaji sekä näiden yhdysvaikutus. Satunnaismuuttujina olivat kerranne ja kerrannexheinäkasvilaji-yhdysvaikutus.

Taulukko 2. Koeruutujen niittoajankohdat vuosina 2004 ja 2005.

\begin{tabular}{lcccc|ccc} 
& \multicolumn{3}{c}{ Niittoajankohdat 2004} & \multicolumn{3}{c}{ Niittoajankohdat 2005 } \\
\hline timotei-nurminata & 1. niitto & 2. niitto & 3. niitto & 4. niitto & 1. niitto & 2. niitto & 3. niitto \\
valkoapila, Jögeva 4 & 7.6. & 5.7. & 19.7. & 26.8. & 9.6. & 30.6. & 2.9. \\
puna-apila, Betty & 7.6. & 5.7. & 27.7. & 26.8. & 9.6. & 30.6. & 24.8. \\
alsikeapila, Frida & 7.6. & 5.7. & 27.7. & 26.8. & 9.6. & 29.6. & 22.8. \\
keltamaite, Leo & 7.6. & 5.7. & 27.7. & 26.8. & 9.6. & 30.6. & 22.8. \\
rehumailanen, Karlu & 15.6. & 13.7. & 25.8. & & 14.6. & 18.7. & 2.9. \\
rehumailanen, Juurlu & 15.6. & 13.7. & 25.8. & & 14.6. & 18.7. & 25.8. \\
\hline timotei-ruokonata & 15.6. & 13.7. & 25.8. & & 14.6. & 18.7. & 25.8. \\
valkoapila, Jögeva 4 & 7.6. & 5.7. & 19.7. & 26.8. & 9.6. & 30.6. & 2.9. \\
puna-apila, Betty & 7.6. & 5.7. & 27.7. & 26.8. & 9.6. & 30.6. & 24.8. \\
alsikeapila, Frida & 7.6. & 5.7. & 27.7. & 26.8. & 9.6. & 29.6. & 22.8. \\
keltamaite, Leo & 7.6. & 5.7. & 27.7. & 26.8. & 9.6. & 30.6. & 22.8. \\
rehumailanen, Karlu & 15.6. & 13.7. & 25.8. & & 14.6. & 18.7. & 2.9. \\
rehumailanen, Juurlu & 15.6. & 13.7. & 25.8. & & 14.6. & 18.7. & 25.8. \\
\hline
\end{tabular}

\section{Tulokset ja tulosten tarkastelu \\ Kasvukausien sää}

Satovuosien kasvukausien keskeiset säätiedot on koottu taulukkoon 3. Kasvukauden sää oli vuonna 2005 huomattavasti lämpimämpi ja vähäsateisempi kuin vuonna 2004. Vertailukauden (1981-2010) keskiarvoihin verrattuna kesä 2004 oli runsassateinen ja kesä 2005 lämmin sekä vähäsateinen.

Taulukko 3. Kasvukausien 2004-2005 säätiedot perustuen Ilmatieteen laitoksen Revonlahden (Siikajoki) sääaseman tietoihin.

\begin{tabular}{lccc|cccc} 
Vuosi & Kasvukausi & $\begin{array}{c}\text { Kasvukauden } \\
\text { pituus }(v r k)\end{array}$ & $\begin{array}{c}\text { Tehoisa lämpö- } \\
\text { summa }\left(>+5^{\circ} \mathrm{C}\right)\end{array}$ & toukokuu & \multicolumn{3}{c}{ Sademäärä $(\mathrm{mm})$} \\
kesäkuu & heinäkuu & elokuu \\
\hline 2004 & $16.4 .-7.10$. & 166 & 1126 & 72 & 56 & 108 & 100 \\
2005 & $3.5 .-15.10$. & 175 & 1245 & 55 & 27 & 55 & 59 \\
$1981-2010$ & & $* 1091$ & 50 & 65 & 83 & 75 \\
\hline
\end{tabular}

* vertailukauden 1981-2010 lämpösumma 15.10. keskiarvon mukaan.

\section{Palkokasvien syys- ja kevättiheydet}

Palkokasvikasvustojen syys- ja kevättiheyksissä (\%) oli selviä eroja sekä palkokasvilajien että koevuosien välillä. Syksyllä 2003 ja keväällä 2004 kaikkien palkokasvikasvustojen keskimääräiset tiheydet olivat välillä 94-100\%. Syksyllä 2003 pienimmät tiheydet määritettiin keltamaitteella timoteinurminataseoksessa (94\%) ja alsikeapilalla timotei-ruokonataseoksessa (96 \%). Keväällä 2004 keltamaiteruuduilla tiheys oli timotei-nurminataseoksessa $98 \%$ ja timotei-ruokonataseoksessa $95 \%$. Muiden palkokasviruutujen kevättiheydeksi määritettiin $100 \%$ keväällä 2004. Syksyllä 2004 keltamaitteen kasvustojen tiheydet olivat romahtaneet edellisen kevään mittauksiin verrattuna. Timoteinurminataseoksessa keltamaitteen syystiheydeksi mitattiin $28 \%$ ja timotei-ruokonataseoksessa ainoastaan $16 \%$. Rehumailasista Juurlun syystiheys timotei-nurminataseoksessa oli $85 \%$ vuonna 2004. Muiden palkokasvien osalta syystiheydet olivat välillä 95-100\%.

Osa palkokasvikasvustoista kärsi talvituhoista, mikä ilmeni kevään 2005 tiheysmittauksista. Tällöin ainoastaan apiloilla mitattiin yli $90 \%$ :n kevättiheydet. Keltamaitteen kevättiheydeksi määritettiin timotei-nurminataseoksessa $53 \%$ ja timotei-ruokonataseoksessa $44 \%$. Karlu-rehumailasen kevättiheydeksi määritettiin timotei-nurminataseoksessa $38 \%$ ja timotei-ruokonataseoksessa $45 \%$. Juurlulajikeella vastaavat tiheydet olivat 79 ja $48 \%$. Tulosten perusteella apilat ovat selkeästi keltamaitetta ja rehumailasta viljelyvarmempia palkokasveja kuvatun kaltaisissa olosuhteissa. 


\section{Eri kasvilajien osuudet sadossa}

Heinäkasvien suhteellinen osuus oli suurin ensimmäisessä niitossa. Myöhemmillä niittokerroilla palkokasvien osuus sadosta lisääntyi. Timotei-ruokonataseoksissa ruokonadan osuus sadosta lisääntyi timotein kustannuksella myöhemmissä niitoissa verrattuna ensimmäiseen niittoon. Myös nurminadan osuus kasvoi timoteihin nähden myöhemmissä niitoissa timotei-nurminataseoksissa. Vuoden 2004 ensimmäisessä niitossa apiloiden osuudet tuorepainosta olivat välillä $27-45 \%$. Toisessa niitossa vastaavat osuudet olivat 61-69\%, kolmannessa 52-73\% ja neljännessä 39-62 \%. Rehumailasta oli suhteellisesti enemmän timotei-ruokonataseoksissa kuin timotei-nurminataseoksissa. Esimerkiksi vuoden 2004 ensimmäisessä niitossa rehumailasen osuus sadon tuorepainosta vaihteli timoteiruokonataseoksessa välillä 27-32 \%, kun vastaava osuus timotei-nurminataseoksessa oli vain 12-14 $\%$. Keltamaitetta oli korjatuissa sadoissa hyvin vähän. Vuoden 2004 ensimmäisessä niitossa keltamailasen osuus tuorepainosta oli $0,7-2,2 \%$. Toisessa niitossa vastaava osuus oli $2,1-4,7 \%$ ja kolmannessa 1,6-9,1\%. Rikkakasveja esiintyi selvästi eniten keltamaite- ja rehumailasseoksissa. Esimerkiksi vuoden 2004 kolmannessa niitossa rikkakasvien suhteellinen osuus oli keltamaiteruuduilla 27-32 \% tuorepainosta. Rehumailasen osalta rikkakasvien osuus oli timotei-nurminataruuduilla kolmannessa niitossa 15-26\% ja timotei-ruokonataruuduilla 4-7\%.

Vuoden 2005 ensimmäisessä niitossa apiloiden osuus tuorepainosta oli 18-46\%. Toisessa niitossa vastaavat osuudet olivat 32-69\% ja kolmannessa 22-50 \%. Apiloista puna-apila vaikutti pärjäävän parhaiten kilpailussa heinäkasvien kanssa, ja sen suhteellinen osuus oli suurempi kuin valko- ja alsikeapilalla. Tosin vuoden 2005 kolmannella niittokerralla alsikeapilan suhteellinen osuus tuoresadosta oli samaa luokkaa (39-50 \%) puna-apilan kanssa. Keltamaitetta ja rehumailasia oli vuoden 2005 korjatuissa sadoissa hyvin vähän $(0,1-14 \%)$. Vuoden 2005 osalta oli havaittavissa myös rikkojen osuuden lisääntyminen keltamaite- ja rehumailasruuduilla. Vuoden 2005 ensimmäisessä niitossa rikkakasvien suhteellinen osuus oli keltamaiteruuduilla 10-17\% sadon tuorepainosta. Toisessa niitossa rikkakasvien osuus oli jo 42-44 \% ja kolmannessa 21-34\%.

\section{Kuiva-aine, energia- ja raakavalkuaissadot}

Heinäkasvilaji ei vaikuttanut merkitsevästi kuiva-aineen kokonaissatoon (kg ka/ha), muuntokelpoisen energian satoon (GJ/ha) eikä raakavalkuaissatoon ( $\mathrm{kg} / \mathrm{ha}$ ) kumpanakaan koevuonna (Taulukot 4 ja 5). Myöskään heinäkasvi×palkokasvi-yhdysvaikutus ei ollut tilastollisesti merkitsevä. Keskimääräinen kokonaiskuiva-ainesato oli $5501 \mathrm{~kg} \mathrm{ka} / \mathrm{ha}$ vuonna 2004 ja $4724 \mathrm{~kg} \mathrm{ka} / \mathrm{ha}$ vuonna 2005. Muuntokelpoisen energian sato oli vastaavasti keskimäärin 60,1 GJ/ha vuonna 2004 ja 51,4 GJ/ha vuonna 2005.

Palkokasvilaji vaikutti merkitsevästi kuiva-aine-, energia- ja raakavalkuaissatoihin molempina koevuosina (Taulukot 4 ja 5). Vuonna 2004 suurimmat kuiva-aine- ja energiasadot mitattiin puhtaista nurmiheinäkasvustoista (6 200-6700 kg ka/ha, 68-73 GJ/ha) sekä nurmiheinäkasvin ja valkoapilan seoskasvustoista (6 300-6 $700 \mathrm{~kg} \mathrm{ka} / \mathrm{ha}, 69-74 \mathrm{GJ} / \mathrm{ha}$ ). Myös heinäkasvin ja puna-apilan seoskasvustoilla saavutettiin yli $5600 \mathrm{~kg} \mathrm{ka} / \mathrm{ha}$ kuiva-ainesadot ja yli $60 \mathrm{GJ} / \mathrm{ha}$ energiasadot. Pienimmiksi satotasot jäivät keltamaitetta sisältäneillä seoskasvustoilla (3 900-4 $100 \mathrm{~kg} \mathrm{ka/ha,} \mathrm{44-46} \mathrm{GJ/ha).} \mathrm{Keltamai-}$ tetta oli korjatuissa sadoissa hyvin vähän, ja näillä ruuduilla suurin osa sadosta muodostui nurmiheinäkasveista sekä rikoista. Rehumailasta sisältävien ruutujen kuiva-ainesato vaihteli vuonna 2004 välillä $4800-5700 \mathrm{~kg} \mathrm{ka} / \mathrm{ha}$ ja energiasato välillä 52-61 GJ/ha. Suurimmat raakavalkuaissadot saatiin vuonna 2004 valkoapilaa sisältäneiltä koeruuduilta (1 150-1 $300 \mathrm{~kg} / \mathrm{ha}$ ). Myös ruuduilta, joilla viljeltiin puna- ja alsikeapilaa timotei-ruokonataseoksessa, korjattiin yli $1000 \mathrm{~kg} / \mathrm{ha}$ raakavalkuaissadot. Puhtailla nurmiheinäkasvustoilla raakavalkuaissato oli 890-950 kg/ha. Rehumailasta ja keltamaitetta sisältäneillä ruuduilla raakavalkuaissato jäi, matalasta kuiva-ainesadosta johtuen, puhtaita nurmiheinäkasvustoja alhaisemmaksi. Vuoden 2004 satotasot eri niittokerroittain on esitetty taulukossa 4.

Vuoden 2005 tulokset olivat samansuuntaiset kuin vuonna 2004, mutta satomäärät jäivät hieman vuotta 2004 alhaisemmiksi (Taulukko 5). Vuonna 2005 korkeimmat kuiva-ainesadot mitattiin apilaa sisältävistä seoskasvustoista (4 650-5 $600 \mathrm{~kg} \mathrm{ka} / \mathrm{ha}$ ) sekä puhtailta heinäkasviruuduilta (4 600-5 $300 \mathrm{~kg} \mathrm{ka} / \mathrm{ha}$ ). Rehumailasta ja keltamaitetta sisältäneillä ruuduilla kuiva-ainesadot vaihtelivat välillä 3 700-4 $500 \mathrm{~kg} \mathrm{ka} / \mathrm{ha}$, mutta suurin osa sadosta muodostui heinäkasveista sekä rikoista. Suurimmat energiasadot saavutettiin vuonna 2005 heinäkasvien ja puna-apilan (58 GJ/ha) sekä heinäkasvien ja valkoapilan (56-60 GJ/ha) seosruuduilta sekä timotei-ruokonataruuduilta (59 GJ/ha). Suurimmat raakavalkuaissadot korjattiin heinäkasvin ja puna-apilan (900-920 kg/ha) sekä heinäkasvin ja valkoapilan seoksista (860-870 kg/ha). Vuoden 2005 yksityiskohtaiset satotasot on esitetty taulukossa 5. 
Taulukko 4. Kuiva-ainesadot (kg ka/ha) sekä muuntokelpoisen energian (GJ/ha) ja raakavalkuaisen (kg/ha) sadot vuonna 2004.

\begin{tabular}{|c|c|c|c|c|c|c|c|c|}
\hline \multirow[b]{2}{*}{ Heinäkasvi } & \multirow[b]{2}{*}{ Palkokasvi } & \multicolumn{5}{|c|}{ Kuiva-ainesato, $\mathrm{kg} \mathrm{ka} / \mathrm{ha}$} & \multirow[b]{2}{*}{$\begin{array}{l}\text { Muuntokelpoisen energian } \\
\text { kokonaissato }(\mathrm{GJ} / \mathrm{ha})\end{array}$} & \multirow[b]{2}{*}{$\begin{array}{l}\text { Raakavalkuaisen } \\
\text { kokonaissato }(\mathrm{kg} / \mathrm{ha})\end{array}$} \\
\hline & & 1. niitto & 2. niitto & 3. niitto & 4. niitto & Kokonaissato & & \\
\hline Timotei/nurminata & Ei palkokasvia & 1043 & 1964 & 1282 & 1914 & 6203 & 68,3 & 891 \\
\hline Timotei/nurminata & Valkoapila (Jögeva 4) & 1287 & 2003 & 1580 & 1446 & 6316 & 69,2 & 1157 \\
\hline Timotei/nurminata & Puna-apila (Betty) & 1409 & 1691 & 1259 & 1290 & 5648 & 61,9 & 958 \\
\hline Timotei/nurminata & Alsikeapila (Frida) & 1515 & 1709 & 931 & 1045 & 5201 & 57,2 & 877 \\
\hline Timotei/nurminata & Keltamaite (Leo) & 1605 & 852 & 1063 & - & 3926 & 43,5 & 358 \\
\hline Timotei/nurminata & Rehumailanen (Karlu) & 2401 & 1380 & 1887 & - & 5667 & 61,1 & 731 \\
\hline Timotei/ruokonata & Ei palkokasvia & 1267 & 1929 & 1150 & 2314 & 6660 & 73,4 & 947 \\
\hline Timotei/ruokonata & Valkoapila (Jögeva 4) & 1585 & 1982 & 1638 & 1501 & 6706 & 73,8 & 1293 \\
\hline Timotei/ruokonata & Puna-apila (Betty) & 1513 & 1660 & 1353 & 1330 & 5857 & 63,3 & 1035 \\
\hline Timotei/ruokonata & Alsikeapila (Frida) & 1514 & 1600 & 1113 & 1245 & 5472 & 60,1 & 1000 \\
\hline Timotei/ruokonata & Keltamaite (Leo) & 1662 & 880 & 1586 & - & 4128 & 45,5 & 435 \\
\hline Timotei/ruokonata & Rehumailanen (Karlu) & 1896 & 1078 & 2135 & - & 5109 & 54,0 & 739 \\
\hline Timotei/ruokonata & Rehumailanen (Juurlu) & 1814 & 1282 & 2239 & - & 5335 & 57,1 & 762 \\
\hline Keskimäärin & & 1602 & 1504 & 1503 & 1511 & 5501 & 60,1 & 846 \\
\hline \multicolumn{9}{|l|}{ Heinäkasvi $^{* * *}$} \\
\hline Timotei/nurminata & & 1597 & 1520 & 1405 & 1424 & 5393 & 59,1 & 804 \\
\hline Timotei/ruokonata & & 1607 & 1487 & 1602 & 1598 & 5610 & 61,0 & 887 \\
\hline SEM $^{*}$ & & 112,1 & 155,2 & 43,7 & 52,7 & 346,0 & 3,65 & 46,4 \\
\hline \multicolumn{9}{|l|}{ Palkokasvi ${ }^{* * * *}$} \\
\hline Ei palkokasvia & & 1155 & 1947 & 1216 & 2114 & 6432 & 70,9 & 919 \\
\hline Valkoapila (Jögeva 4) & & 1436 & 1992 & 1609 & 1473 & 6511 & 71,5 & 1225 \\
\hline Puna-apila (Betty) & & 1461 & 1675 & 1306 & 1310 & 5752 & 62,6 & 997 \\
\hline Alsikeapila (Frida) & & 1515 & 1655 & 1022 & 1145 & 5336 & 58,7 & 939 \\
\hline Keltamaite (Leo) & & 1634 & 866 & 1325 & - & 4027 & 44,5 & 396 \\
\hline Rehumailanen (Karlu) & & 2149 & 1229 & 2011 & - & 5388 & 57,6 & 735 \\
\hline Rehumailanen (Juurlu) & & 1865 & 1162 & 2034 & - & 5062 & 54,7 & 709 \\
\hline SEM $^{*}$ & & 120,9 & 161,8 & 76,2 & 54,7 & 343,6 & 3,63 & 54,6 \\
\hline \multirow[t]{3}{*}{$p$-arvo } & heinäkasvi & 0,94 & 0,79 & $<0,001$ & 0,058 & 0,58 & 0,63 & 0,073 \\
\hline & palkokasvi & $<0,001$ & $<0,001$ & $<0,001$ & $<0,001$ & $<0,001$ & $<0,001$ & $<0,001$ \\
\hline & heinäkasvi×palkokasvi & 0,075 & 0,41 & 0,033 & 0,011 & 0,45 & 0,36 & 0,83 \\
\hline
\end{tabular}

${ }^{*}$ SEM = keskiarvon keskivirhe. ${ }^{* *} /{ }^{* * *}$ Satoluvut viittaavat kokonaissatoihin (sisältävät sekä heinä- että palkokasvit): tässä ne on laskettu keskiarvoina joko heinäseoksittain erittelemättä palkokasvivaihtoehtoa $\left(^{* *}\right)$ tai eri palkokasvivaihtoehdoin erittelemättä heinäseosta $\left(^{* * *}\right)$. 
Taulukko 5. Kuiva-ainesadot (kg ka/ha) sekä muuntokelpoisen energian (GJ/ha) ja raakavalkuaisen (kg/ha) sadot vuonna 2005.

\begin{tabular}{|c|c|c|c|c|c|c|c|}
\hline \multirow[b]{2}{*}{ Heinäkasvi } & \multirow[b]{2}{*}{ Palkokasvi } & \multicolumn{4}{|c|}{ Kuiva-ainesato (kg ka/ha) } & \multirow[b]{2}{*}{$\begin{array}{l}\text { Muuntokelpoisen energian } \\
\text { kokonaissato }(\mathrm{GJ} / \mathrm{ha})\end{array}$} & \multirow[b]{2}{*}{$\begin{array}{l}\text { Raakavalkuaisen } \\
\text { kokonaissato }(\mathrm{kg} / \mathrm{ha})\end{array}$} \\
\hline & & 1. niitto & 2. niitto & 3. niitto & Kokonaissato & & \\
\hline Timotei/nurminata & Ei palkokasvia & 1645 & 1946 & 998 & 4593 & 50,9 & 602 \\
\hline Timotei/nurminata & Valkoapila (Jögeva 4) & 1007 & 2591 & 1694 & 5301 & 56,4 & 862 \\
\hline Timotei/nurminata & Puna-apila (Betty) & 1168 & 2467 & 1734 & 5376 & 58,4 & 921 \\
\hline Timotei/nurminata & Alsikeapila (Frida) & 1108 & 2164 & 1374 & 4654 & 50,1 & 735 \\
\hline Timotei/nurminata & Keltamaite (Leo) & 1890 & 1461 & 1098 & 4462 & 48,6 & 615 \\
\hline Timotei/nurminata & Rehumailanen (Karlu) & 1713 & 1281 & 945 & 3944 & 43,2 & 510 \\
\hline Timotei/nurminata & Rehumailanen (Juurlu) & 1851 & 1521 & 1061 & 4445 & 48,5 & 668 \\
\hline Timotei/ruokonata & Ei palkokasvia & 1973 & 1860 & 1463 & 5304 & 58,5 & 648 \\
\hline Timotei/ruokonata & Valkoapila (Jögeva 4) & 1188 & 2418 & 1967 & 5574 & 60,0 & 871 \\
\hline Timotei/ruokonata & Puna-apila (Betty) & 1275 & 2090 & 1903 & 5270 & 57,7 & 904 \\
\hline Timotei/ruokonata & Alsikeapila (Frida) & 1331 & 1897 & 1682 & 4911 & 52,7 & 769 \\
\hline Timotei/ruokonata & Keltamaite (Leo) & 1797 & 1365 & 1238 & 4411 & 47,7 & 567 \\
\hline Timotei/ruokonata & Rehumailanen (Karlu) & 1627 & 1103 & 922 & 3670 & 40,4 & 447 \\
\hline Timotei/ruokonata & Rehumailanen (Juurlu) & 1724 & 1323 & 1162 & 4225 & 46,2 & 555 \\
\hline Keskimäärin & & 1521 & 1821 & 1372 & 4724 & 51,4 & 691 \\
\hline SEM $^{*}$ & & & 133,7 & 159,9 & 296,1 & 3,06 & 56,1 \\
\hline \multicolumn{8}{|l|}{ Heinäkasvi $^{* * * *}$} \\
\hline Timotei/nurminata & & 1440 & 1919 & 1268 & 4682 & 50,8 & 702 \\
\hline Timotei/ruokonata & & 1535 & 1722 & 1477 & 4766 & 51,9 & 680 \\
\hline SEM $^{*}$ & & & 68,8 & 91,8 & 177,7 & 1,82 & 28,2 \\
\hline \multicolumn{8}{|l|}{ Palkokasvi ${ }^{* * * * *}$} \\
\hline Ei palkokasvia & & 1802 & 1903 & 1231 & 4948 & 54,7 & 625 \\
\hline Valkoapila (Jögeva 4) & & 1094 & 2505 & 1831 & 5438 & 58,2 & 866 \\
\hline Puna-apila (Betty) & & 1220 & 2278 & 1819 & 5323 & 58,1 & 912 \\
\hline Alsikeapila (Frida) & & 1214 & 2031 & 1528 & 4782 & 51,4 & 752 \\
\hline Keltamaite (Leo) & & 1843 & 1413 & 1168 & 4437 & 48,1 & 591 \\
\hline Rehumailanen (Karlu) & & 1669 & 1192 & 934 & 3807 & 41,8 & 478 \\
\hline Rehumailanen (Juurlu) & & 1786 & 1422 & 1097 & 4335 & 47,4 & 611 \\
\hline SEM $^{*}$ & & & 101,0 & 113,0 & 209,4 & 2,17 & 41,0 \\
\hline \multirow[t]{3}{*}{$p$-arvo } & heinäkasvi & 0,32 & 0,005 & 0,16 & 0,75 & 0,70 & 0,57 \\
\hline & palkokasvi & $<0,001$ & $<0,001$ & $<0,001$ & $<0,001$ & $<0,001$ & $<0,001$ \\
\hline & heinäkasvi×palkokasvi & 0,029 & 0,92 & 0,72 & 0,48 & 0,45 & 0,74 \\
\hline
\end{tabular}

${ }^{*}$ SEM = keskiarvon keskivirhe. ${ }^{* *}$ Aineiston tilastollisessa käsittelyssä käytetty logaritmimuunnosta, jolloin SEM-arvoa ei voida antaa. ${ }^{* * * *} /{ }^{* * * * *}$ Satoluvut viittaavat kokonaissatoihin (sisältävät sekä heinä- että palkokasvit): tässä ne on laskettu keskiarvoina joko heinäseoksittain erittelemättä palkokasvivaihtoehtoa ${ }^{* * *}$ ) tai eri palkokasvivaihtoehdoin erittelmättä heinäseosta $\left({ }^{* * * *}\right)$. 


\section{Rehun laatu}

Molempina koevuosina korkeimmat D-arvot mitattiin odotetusti ensimmäisen niiton sadoista (keskimäärin $722 \mathrm{~g} / \mathrm{kg}$ ka vuonna $2004 \mathrm{ja} 739 \mathrm{~g} / \mathrm{kg}$ ka vuonna 2005). Myöhemmillä niittokerroilla D-arvot olivat pääosin alle $700 \mathrm{~g} / \mathrm{kg} \mathrm{ka}$. Vuonna 2004 heinäkasvilaji vaikutti tilastollisesti merkitsevästi $(p=0,008) \mathrm{D}$-arvon kuiva-ainesadoilla painotettuun keskiarvoon, joka oli timotei-nurminadalla hieman korkeampi (686 g/kg ka) timotei-ruokonataan $(680 \mathrm{~g} / \mathrm{kg} \mathrm{ka})$ verrattuna. Vuonna 2005 vastaavaa vaikutusta ei havaittu. Heinäkasvixpalkokasvi-yhdysvaikutus ei ollut D-arvojen osalta tilastollisesti merkitsevä kumpanakaan koevuonna. Palkokasvien osalta vuonna 2004 matalimmat kuiva-ainesadolla painotetut D-arvot mitattiin rehumailasten ja heinäkasvien seosruuduilta (661-683 g/kg ka). Korkeimmat Darvot olivat tällöin puhtailla nurmiheinäkasviruuduilla $(689 \mathrm{~g} / \mathrm{kg} \mathrm{ka})$ sekä keltamaitetta sisältäneillä seoskasvustoilla (687-695 g/kg ka). Vuonna 2005 matalimmat kuiva-ainesadolla painotetut D-arvot mitattiin puolestaan valkoapilan ja heinäkasvien (665-673 g/kg ka) ja alsikeapilan ja heinäkasvien (670-674) seosruuduilta. Rehun laatutuloksia tarkasteltaessa on syytä muistaa, että varsinkin vuonna 2005 rehumailasta ja keltamaitetta sisältäneillä ruuduilla suurin osa sadosta muodostui heinäkasveista sekä rikoista. Näin ollen rehumailasen ja keltamaitteen vaikutuksista rehun laatumuuttujiin ei pystytä tämän tutkimuksen perusteella juurikaan ottamaan kantaa.

Heinäkasvilaji ei vaikuttanut tilastollisesti merkitsevästi raakavalkuaispitoisuuteen kumpanakaan koevuonna $(p>0,05)$. Myöskään heinäkasvixpalkokasvi-yhdysvaikutus ei ollut tilastollisesti merkitsevä kumpanakaan koevuonna. Sen sijaan palkokasvin vaikutus sadon raakavalkuaispitoisuuteen oli tilastollisesti merkitsevä $(p<0,001)$ molempina koevuosina kaikilla niittokerroilla. Vuonna 2004 raakavalkuaispitoisuuden kuiva-ainesadolla painotettu keskiarvo oli korkein apilaa sisältäneissä seoskasvustoissa (valkoapila $188 \mathrm{~g} / \mathrm{kg} \mathrm{ka}$, alsikeapila $176 \mathrm{~g} / \mathrm{kg} \mathrm{ka} \mathrm{ja} \mathrm{puna-apila} 173 \mathrm{~g} / \mathrm{kg} \mathrm{ka}$ ). Puhtaiden heinäkasvinurmien raakavalkuaispitoisuus oli keskimäärin vastaavasti $143 \mathrm{~g} / \mathrm{kg}$ ka. Matalimmaksi raakavalkuaispitoisuus jäi heinäkasveja ja rikkoja sisältäneillä keltamaitteen seosruuduilla (108 g/kg ka). Vuoden 2005 raakavalkuaispitoisuudet vastasivat pääosin vuoden 2004 tuloksia, mutta olivat hieman alemmalla tasolla vuoteen 2004 verrattuna. Myös vuonna 2005 raakavalkuaispitoisuuden kuivaainesadolla painotettu keskiarvo oli korkein apilaa sisältäneissä seoskasvustoissa (puna-apila $172 \mathrm{~g} / \mathrm{kg}$ $\mathrm{ka}$, valkoapila $159 \mathrm{~g} / \mathrm{kg} \mathrm{ka}$, alsikeapila $157 \mathrm{~g} / \mathrm{kg} \mathrm{ka}$ ). Puhtaiden heinäkasvinurmien raakavalkuaispitoisuus oli keskimäärin vastaavasti $127 \mathrm{~g} / \mathrm{kg}$ ka.

Heinäkasvilaji ei vaikuttanut tilastollisesti merkitsevästi NDF-pitoisuuteen kumpanakaan koevuonna. Myöskään heinäkasvixpalkokasvi-yhdysvaikutus ei ollut tilastollisesti merkitsevä kumpanakaan koevuonna. Sen sijaan palkokasvin vaikutus sadon NDF-pitoisuuteen oli tilastollisesti merkitsevä $(p<0,001)$ molempina koevuosina kaikilla niittokerroilla. Kasvuston NDF-pitoisuudet olivat korkeimmat puhtaissa heinäkasvikasvustoissa. Palkokasvin osuuden lisääntyminen sadossa pienensi korjatun sadon kuitupitoisuutta. Tässä raportoitua yksityiskohtaisemmat koetulokset on saatavilla Huuskosen ym. (2012) julkaisusta.

\section{Yhteenveto ja johtopäätökset}

Tulosten perusteella apilat osoittautuivat tällä koejärjestelyllä selkeästi mailasia ja keltamaitetta paremmiksi ja viljelyvarmemmiksi vaihtoehdoiksi nurmiheinäkasvien ja nurmipalkokasvien seosviljelyyn Pohjois-Pohjanmaan olosuhteissa. Puna- ja valkoapilan välillä ei havaittu merkittäviä eroja sadon määrää ja laatua kuvaavissa muuttujissa. Alsikeapilalla saavutettiin hieman puna- ja valkoapilakasvustoja matalammat satotasot. Heinäkasvin ja apiloiden seoskasvustojen D-arvot eivät juuri poikenneet puhtaiden heinäkasvikasvustojen D-arvoista. Sen sijaan seoskasvustot sisälsivät enemmän raakavalkuaista ja vähemmän kuitua kuin puhtaat nurmiheinäkasvustot. Varsinkin jälkimmäisenä satovuonna rehumailasta ja keltamaitetta sisältäneillä ruuduilla suurin osa sadosta muodostui heinäkasveista sekä rikoista. Näin ollen rehumailasen ja keltamaitteen vaikutuksista rehun laatumuuttujiin ei pystytä tämän tutkimuksen perusteella juurikaan ottamaan kantaa.

\section{Kirjallisuus}

Huhtanen, P., Nousiainen, J, \& Rinne, M. 2006. Recent developments in forage evaluation with special reference to practical applications. Agric. Food Sci. 15: 293-323.

Huuskonen, A., Niemelä, M., Hyrkäs, M. \& Luoma, S. 2012. Nurmipalkokasveja viljelyyn ja laidunnukseen. MTT Raportti 77: 53-75. 